\title{
Comparison of morphine, ketoprofen and Arnica montana 6x and 30x per oral transmucosal or subcutaneous route for control of postoperative pain in cats subjected to hysterectomy with bilateral salpingo-oophorectomy
}

\author{
Comparação de morfina, cetoprofeno e Arnica montana 6x e 30x por \\ via transmucosa oral ou subcutânea para control e de dor pós-operatória \\ em gatas submetidas à histerectomia e ooforectomia bilateral
}

\author{
Denise de Fátima Rodrigues ${ }^{\mathrm{I}}$ Stelio Pacca Loureiro Luna ${ }^{\mathrm{I}}$ \\ Juliana Tabarelli Brondani ${ }^{\mathrm{I}}$ Bruno Watanabe Minto $^{\mathrm{II}}$
}

\section{ABSTRACT}

The postoperative analgesic effect of Arnica montana (Arnica) was compared to morphine and ketoprofen in 50 cats following hysterectomy with bilateral salpingo-oophorectomy (HSO). Cats were randomly allocated to five groups $(n=10)$ and were treated 30 minutes before surgery and over 72 hours with Iml of Arnica 30x per subcutaneous (SC) route (GA30SC); Arnica $30 x$ per oral transmucosal route (P.O.) (GA30PO); Arnica $6 x$ P.O. (GA6PO); morphine $0.1 \mathrm{mg} \mathrm{kg}^{-1} \mathrm{SC}$ (GM) SID or ketoprofen $2 m g \mathrm{~kg}^{-1} S C(G K)$ before and $1 \mathrm{mg} \mathrm{kg}^{-1}$ after surgery. Sedation and postoperative pain were assessed by means of a dynamic and interactive visual analogue scale (DIVAS) and variable count scale (VCS) and hyperalgesia using an esthesiometer. Whenever the VAS and VCS scores attained 33\% of the maximum value, rescue analgesia was performed with morphine $0.3 \mathrm{mg} \mathrm{kg}^{-1} \mathrm{per}$ the intramuscular (IM) route. Other variables assessed were vomiting, defecation, urination, body weight and wound healing. Vomiting only occurred in animals treated with morphine. The groups did not differ in defecation, urination, body weight or wound healing. Hyperalgesia was detected only on the occasions that the criterion for rescue analgesia was met. One animal in GK and one in $G M$ required rescue analgesia, differing from groups GA30SC, GA30PO and GA6PO, in which 4, 4 and 5 animals, respectively, required rescue analgesia. It can be concluded that ketoprofen and morphine were more efficacious than Arnica and that there was no difference among the various potencies and routes of administration of Arnica for postoperative analgesia in cats undergoing HSO.

Key words: ovariohysterectomy, spay, homeopathy, analgesia.

\section{RESUMO}

Comparou-se o efeito analgésico de Arnica em relação à morfina ou cetoprofeno, no periodo pós-operatório, de 50 gatas submetidas à ovariossalpingohisterectomia (OSH).
As gatas foram divididas em cinco grupos $(n=10)$ e tratadas aleatoriamente 30 minutos antes da cirurgia por 72 horas com $1 \mathrm{ml}$ de Arnica 30D por via subcutânea (SC) (GA30SC); Arnica $30 D$ por via oral (VO) (GA30VO); Arnica $6 D$ VO (GA6VO); 0,1mg $\mathrm{kg}^{-1}$ de morfina SC (GM) TID ou $2 \mathrm{mg} \mathrm{kg}^{-1}$ de cetoprofeno SC (GC) antes e $1 \mathrm{mg} \mathrm{kg}^{-1}$ após a cirurgia SID. Foram avaliadas a sedação e a dor pós-operatória, por meio de escala analógica visual (EAV), escala de contagem variável (ECV) e hiperalgesia, esta última pelo estesiometro. Quando os escores da ECV e EAV atingiram 33\% do valor máximo, realizou-se resgate analgésico com $0,3 \mathrm{mg} \mathrm{kg}^{-1}$ de morfina por via intramuscular (IM). Observou-se ocorrência de vômito, defecação, micção, alteração de peso e a cicatrização. Exceto nos animais tratados com morfina, não houve vômito. Não houve diferença entre os grupos para defecação, micção, peso e cicatrização. A hiperalgesia foi observada apenas nos momentos do resgate analgésico. Um animal de GC e um de GM receberam resgate analgésico, o que diferiu dos grupos GA30SC, GA30VO e GA6VO, onde, respectivamente, 4, 4 e 5 animais necessitaram resgate analgésico. Conclui-se que o cetoprofeno e a morfina foram mais eficazes que a Arnica e que, quanto à Arnica, não houve diferença nem entre as dinamizações e entre as vias SC e oral para analgesia de gatas submetidas à $\mathrm{OSH}$.

Palavras-chave: ovariosalpingohisterectomia, homeopatia, analgesia.

\section{INTRODUCTION}

Drugs used to minimize pain include nonsteroidal anti-inflammatory drugs (NSAIDs), opioids (TAYLOR \& ROBERTSON, 2004), herbal medicines and homeopathic remedies, Arnica in particular (VILELLA et al., 2009; CASSU et al., 2011). While NSAIDs exhibit adequate analgesic efficacy, they are associated with

\footnotetext{
'Programa de Pós-graduação, Faculdade de Medicina Veterinária e Zooctecnia (FMVZ), Universidade Estadual Paulista (UNESP), 18618-970, Botucatu, SP, Brasil. E-mail: steliopacca@gmail.com. "Corresponding author.

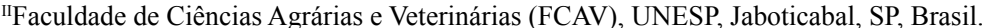


significant adverse effects in cats and dogs, such as gastroenteritis, hemostatic alterations and reduction of renal blood flow (LUNA et al., 2006; TAKATA et al., 2012). Opioids can also cause adverse effects, such as respiratory depression, constipation, nausea, vomiting and histamine release (TAYLOR et al., 1999; GUEDES et al., 2006; ROBERTSON et al., 2009).

Arnica is one of the most widely investigated homeopathic medicines as an analgesic. The active ingredients of the source plant are sesquiterpene lactones, such as helenalin, 11[alpha],13-dihydrohelenalin, chamissonolide and their esters. In its phytotherapy use, Arnica reduces inflammation, by inhibiting nuclear factor [kappa] B (NF-kB), similar to the inhibition induced by corticoids, which controls the transcription of many genes encoding cytokines such as interleukin (IL)-1, IL-2, IL-6, IL-8 and tumor necrosis factor (MACEDO et al., 2004; SEEMANN et al., 2010).

While reports on the use of homeopathy for pain relief in cats are few in the literature (MENEGHELLO, 2002), the results are promising in dogs (VILELLA et al., 2009, CASSU et al., 2011) and human beings in treating injuries and contusions (JEFFREY \& BELCHER, 2002) and in reducing inflammation and pain (ROBERTSON et al., 2007). However, there are also conflicting, nonpromising results relative to the analgesic properties of Arnica (VICKERS et al., 1998; STEVINSON et al., 2003), which suggests the need to perform studies to demonstrate or rule out its efficacy in this regard, specifically in felines.

The search for inexpensive approaches for the treatment of animals, independence from the pharmaceutical industry, absence of residuals and adverse effects in the animal organism, and easy administration of drugs, are all factors that stimulate the performance of studies assessing the analgesic efficacy of Arnica in cats. The use of the oral route may be difficult with felines in the case of drugs that must be swallowed. Thus, one of the advantages of Arnica is that it does not need to be swallowed when delivered P.O. In addition, it may also be injected when the oral route cannot be used, as the results of injected Arnica in the treatment of pain are also promising (MARIANI et al., 2009).

One important issue in the case of homeopathic medicines is the need to adjust their potency as a function of the clinical condition of the patient. Low potencies $(3$ to $12 \mathrm{cH}$ and 6 to $24 \mathrm{x})$ are indicated for acute illnesses and should be administered often. Middle potencies $(15 \mathrm{cH}$ or $30 \mathrm{x}$ ) are usually used in subacute conditions and may be administered less often, as a function of the longer duration of their effect (BENEZ, 2002). However, these indications are empirical and have not been subjected to rigorous scientific assessment.

The objective of the present study was to assess the analgesic efficacy of Arnica montana after hysterectomy with bilateral salpingo-oophorectomy (HSO) in cats compared to ketoprofen and morphine. In addition, the analgesic efficacies of Arnica at various potencies and administered P.O. or subcutaneous (SC) route were compared based on the following hypotheses: 1. the analgesic effects of Arnica delivered per oral transmucosal or SC route before and after surgery are as efficient as those of ketoprofen; 2. the analgesic effect of Arnica delivered per SC route is as efficient as the one of Arnica administered per oral transmucosal route; and 3. the efficacy of Arnica 30x is higher than that of Arnica 6x.

\section{MATERIALS AND METHODS}

Fifty healthy cats of various breeds, aged six months to two years old and weighing 2 to $4 \mathrm{~kg}$ (2.67 \pm 0.12$)$, were used. They were randomly allocated to five groups with 10 animals each and were treated with: 1ml of Arnica 30x SC (GA30SC); 1ml of Arnica 30x P.O. (GA30PO); $1 \mathrm{ml}$ of Arnica 6x P.O. (GA6PO); morphine $0.1 \mathrm{mg} / \mathrm{kg} \mathrm{SC}(\mathrm{GM})$; or ketoprofen $2 \mathrm{mg} / \mathrm{kg}$ $\mathrm{SC}(\mathrm{GK})$. All of the treatments were administered 30 minutes before surgery and then every 12 hours over 72 hours, except for ketoprofen, which was administered every 24 hours at a dose of $1 \mathrm{mg} / \mathrm{kg}$ after surgery. In addition, $1 \mathrm{ml}$ of $0.9 \% \mathrm{NaCl}$ was administered P.O. or $\mathrm{SC}$ as placebo to simulate the treatments of the other groups, when these routes were not used.

All assessments, animal handling, sample collections and drug administration were performed by the same investigator blind to the treatments. The same surgeon performed animals minimally invasive HSO by means of the hook technique.

Eight hours before surgery, the animals behavior was assessed by DIVAS, UNESP - Botucatu multidimensional composite acute pain scale for cats (VCS) (BRONDANI et al., 2012; BRONDANI et al., 2013) and assessment of sensitivity using von Frey monofilaments. Only the animals rated healthy after a complete clinical examination and with normal complete blood count and biochemical tests (urea, creatinine, alanine aminotransferase, and alkaline phosphatase) were included in the study.

The animals were sedated using acepromazine $\quad 0.05 \mathrm{mg} / \mathrm{kg}$ intramuscularly (IM) 40 minutes before surgery. The analgesics were administered and anesthesia was induced with up to $5 \mathrm{mg} / \mathrm{kg}$ of propofol and $2 \mu \mathrm{g} / \mathrm{kg}$ of fentanyl 
intravenously (IV), followed by endotracheal intubation and maintenance with isoflurane, through a non-rebreathing circuit.

Degree of sedation and pain was assessed before and 1, 2, 4, 6, 8, 12, 24, 48 and 72 hours after surgery and on postoperative day 10 , on the occasion of stitch removal. Sedation was assessed by a VAS (adapted from STANWAY et al., 2002) and a sedation score (adapted from DOBBINS et al., 2002). Pain was assessed by means of DIVAS (CAMBRIDGE et al., 2000) and VCS (BRONDANI et al., 2011). Whenever the scores on VCS and DIVAS were over $33 \%$ of the maximum value, morphine $0.3 \mathrm{mg} / \mathrm{kg}$ was administered as rescue analgesic.

Hyperalgesia was assessed using von Frey monofilaments (VALADÃO et al., 2002). Weight gain or loss, defecation, vomiting, difficulty and frequency of urination, post-operative complications, such as edema, inflammation, infection, and dehiscence and rejection of sutures were assessed, in the preoperative period and daily for 72 hours.

The variables body weight, defecation, urination and DIVAS score were analyzed by means of repeated measures analysis of variance (ANOVA) followed by Tukey's test; in the cases of VAS, sedation score and VCS, Kruskal-Wallis test $(\mathrm{P}<0.05)$ was used; and the other parameters were assessed by chi-square test $(\mathrm{P}<0.05)$.

\section{RESULTS AND DISCUSSION}

Body weight and age did not differ among the groups. There was no difference in weight gain among the groups. There were no alterations in the defecation and urination.

Vomiting occurred in three animals from GM in the postoperative period; while this was not significantly different among the groups. Vomiting did not occur in any animal treated with Arnica, which demonstrates the lack of adverse effects of this agent. The fact that homeopathic medicines do not cause adverse effects is well documented. This is an important basis for the indication of homeopathy and represents an advantage of this treatment modality (ROBERTSON et al., 2007; VILELLA et al., 2009).

Wound healing was normal in all groups; no evident edema, dehiscence or any other complications occurred. Reduction of edema supports the indication of Arnica in mechanical traumatic injury characterized by bleeding and bruising (STEVINSON et al., 2003).

The score on DIVAS was higher in GA30SC compared to GK at 2 hours after surgery; the scores were higher in GA30PO and GA6PO compared to the other groups at the 4-hour assessment. Higher VCS scores compared to baseline were found 1 to 4,8 , 12 and 24 hours after surgery in GA30PO, GA6PO, GA30SC and GM, and in GK respectively (Table 1). Proportions of animals that did not permit using the von Frey filaments, including the thinnest $(5 \mathrm{mN})$, were lower in GK and GM $(6.25 \%)$ compared to GA30SC (18.75\%), GA30PO (31.25\%) and GA6PO $(37.5 \%)$ (Table 2$)$. The latter three groups did not differ in this regard.

One animal in GK and one in GM required rescue analgesia, thus differing from GA30SC,

Table 1 - Medians and quartiles (25\% and $75 \%)$ values of the VCS pain score of cats undergoing HSO and treated before and after surgery with Arnica montana 30x SC (GA30SC); 30x P.O. (GA30PO); or 6x P.O. (GA6PO); ketoprofen SC (GK) or morphine SC (GM) $(\mathrm{n}=10)$.

\begin{tabular}{|c|c|c|c|c|c|}
\hline \multirow{2}{*}{ Time (h) } & \multicolumn{5}{|c|}{-Group---- } \\
\hline & GA30SC & GA30PO & GA6PO & GK & GM \\
\hline 0 & $0(0-0)^{\mathrm{C}}$ & $0(0-0)^{\mathrm{B}}$ & $0(0-0)^{\mathrm{C}}$ & $0(0-0)^{\mathrm{C}}$ & $0(0-0)^{\mathrm{C}}$ \\
\hline 1 & $1.5(1-2)^{\mathrm{A}}$ & $2.5(1-3)^{\mathrm{A}}$ & $1(1-2)^{\mathrm{AB}}$ & $1(1-2)^{\mathrm{A}}$ & $1.5(1-3)^{\mathrm{A}}$ \\
\hline 2 & $3(1-10)^{\mathrm{A}}$ & $3(1-4)^{\mathrm{A}}$ & $2(1-5)^{\mathrm{A}}$ & $2(1-2)^{\mathrm{A}}$ & $2(1-2)^{\mathrm{A}}$ \\
\hline 4 & $2(1-2)^{\mathrm{A}}$ & $7(1-12)^{A}$ & $2(2-10)^{A}$ & $2(1-2)^{\mathrm{A}}$ & $1.5(1-2)^{\mathrm{A}}$ \\
\hline 6 & $1.5(1-2)^{\mathrm{A}}$ & $2(1-2)^{\mathrm{AB}}$ & $2(1-2)^{\mathrm{AB}}$ & $1.5(1-2)^{\mathrm{A}}$ & $1.5(1-2)^{\mathrm{A}}$ \\
\hline 8 & $1.5(1-2)^{\mathrm{A}}$ & $2(1-20)^{\mathrm{AB}}$ & $1(1-2)^{\mathrm{AB}}$ & $1(1-2)^{\mathrm{AB}}$ & $1(1-2)^{\mathrm{AB}}$ \\
\hline 12 & $1(1-1)^{\mathrm{AB}}$ & $1(1-2)^{B}$ & $1(1-1)^{\mathrm{ABC}}$ & $1(1-1)^{\mathrm{AB}}$ & $1(1-1)^{\mathrm{AB}}$ \\
\hline 24 & $1(1-1)^{\mathrm{ABC}}$ & $1.0(1-1)^{\mathrm{B}}$ & $1(1-2)^{\mathrm{AB}}$ & $1(1-1)^{\mathrm{AB}}$ & $1(1-1)^{\mathrm{ABC}}$ \\
\hline 48 & $1(1-1)^{\mathrm{BC}}$ & $1(1-1)^{\mathrm{B}}$ & $1(1-1)^{\mathrm{ABC}}$ & $1.0(1-1)^{\mathrm{BC}}$ & $1(1-1)^{\mathrm{ABC}}$ \\
\hline 72 & $0(0-0)^{\mathrm{BC}}$ & $0(0-1)^{B}$ & $1(0-1)^{\mathrm{BC}}$ & $0(0-0)^{\mathrm{BC}}$ & $0(0-0)^{\mathrm{BC}}$ \\
\hline 240 & $0(0-0)^{\mathrm{C}}$ & $0(0-0)^{\mathrm{B}}$ & $0(0-0)^{\mathrm{C}}$ & $0(0-0)^{\mathrm{C}}$ & $0(0-0)^{\mathrm{C}}$ \\
\hline
\end{tabular}

Different uppercase letters represent intragroup differences over time; Tukey's test $(\mathrm{P}<0.05)$, with $\mathrm{A}>\mathrm{B}>\mathrm{C}$.

Ciência Rural, v.46, n.2, fev, 2016. 
Table 2 - Numbers of cats that required rescue analgesia and that refused the von Frey filaments over time after having undergone HSO and having been treated before and after surgery with Arnica montana 30x SC (GA30SC); Arnica montana 30x P.O. (GA30PO); Arnica montana 6x P.O. (GA6PO); ketoprofen SC (GK) or morphine SC (GM) (n=10).

\begin{tabular}{|c|c|c|c|c|c|c|c|c|c|c|c|}
\hline \multirow{2}{*}{ Group } & \multirow[b]{2}{*}{0} & \multirow[b]{2}{*}{1} & \multirow[b]{2}{*}{2} & \multirow[b]{2}{*}{4} & \multirow[b]{2}{*}{6} & \multirow[b]{2}{*}{8} & \multirow[b]{2}{*}{12} & \multirow[b]{2}{*}{24} & \multirow[b]{2}{*}{48} & \multirow[b]{2}{*}{72} & \multirow[b]{2}{*}{240} \\
\hline & & & & & & & & & & & \\
\hline GA30SC & 0 & 0 & 3 & 1 & 0 & 0 & 0 & 0 & 0 & 0 & 0 \\
\hline GA30PO & 0 & 0 & 0 & 4 & 0 & 0 & 0 & 0 & 0 & 0 & 0 \\
\hline GA6PO & 0 & 0 & 2 & 3 & 0 & 0 & 0 & 0 & 0 & 0 & 0 \\
\hline GK & 0 & 1 & 0 & 0 & 0 & 0 & 0 & 0 & 0 & 0 & 0 \\
\hline GM & 0 & 0 & 1 & 0 & 0 & 0 & 0 & 0 & 0 & 0 & 0 \\
\hline
\end{tabular}

GA30PO and GA6PO, in which 4, 4 and 5 animals, respectively, required rescue medication (Table 2). This indicates that ketoprofen and morphine were more efficient in controlling pain in the postoperative period and in avoiding the occurrence of hyperalgesia in cats undergoing HSO compared to Arnica in any of the three tested regimens. No difference was found in this regard among the three groups administered Arnica. Rescue analgesic was always administered one to four hours after surgery, without needing repetitions. Comparison of these findings to a previous study (BRONDANI et al., 2009), in which the same pain assessment scale, surgical technique and experimental conditions were applied, revealed that $100 \%$ of the animals which was not given analgesic medication required rescue therapy, with an average of 2.75 episodes per animal. Thus, Arnica in the three tested regimens exhibited some effects in the prevention of hyperalgesia starting at least six hours after surgery and in $60 \%$ (GA30SC, GA30PO) or $50 \%$ (GA6PO) of the animals during the entire postoperative period. Therefore, while Arnica may not be as efficient as an analgesic and for avoiding hyperalgesia as ketoprofen and morphine in the immediate postoperative period, it did not differ from the latter in the remainder of the time, i.e., 6 to 240 hours after surgery. This fact is shown by the observation that rescue analgesia was not needed during that period of time.

In the present study, although Arnica was not as efficacious as morphine and ketoprofen in the first six hours after surgery, it may be useful for use at home after this period, because it is known that animals treated with analgesics benefited for up to 56 hours after HSO compared to untreated animals (BRONDANI et al., 2009).

Regarding the investigated routes of administration, SC administration did not show any advantage over the oral one, for which there is no justification for the use of injected Arnica, except when oral delivery is not possible. Similarly, there was no difference between the two tested potencies (6x and 30x); thus, they may be used indistinctly.

The scientific status of homeopathy is controversial. A small number of studies is available in the literature and in the particular case of Arnica, the data are poorly consistent or conflicting relative to its anti-inflammatory and/or analgesic effects (CORNU et al., 2010), resulting in strong criticism (ERNST, 2007), despite reports of positive effects (ROBERTSON et al., 2007). In addition, a significant portion of the studies compared the efficacy of Arnica versus placebo, rather than Arnica versus drugs sanctioned for use in medicine (BRINKHAUS et al., 2006, CORNU et al., 2010). However, the studies that demonstrated the inefficacy of Arnica montana (STEVINSON et al., 2003) exhibit considerable methodological flaws and are questionable. A closer analysis shows that, overall, both the studies favorable (BRINKHAUS et al., 2006) and unfavorable (STEVINSON et al., 2003, CORNU et al., 2010) to the analgesic efficacy of Arnica have poor methodological quality. In veterinary medicine, systematic reviews (CLAUSEN et al., 2013) and databases (MATHIE et al., 2010; 2012) on homeopathic treatment are still incipient. Nevertheless, some clinical studies have shown that Arnica $12 \mathrm{cH}$ potentiated the anti-inflammatory effect of meloxicam, as shown by the reduction of edema compared to the use of the NSAID alone (VILELLA et al., 2009). Additionally, Arnica 12cH was as effective as ketoprofen in dogs subjected to HSO when administered 60 minutes before the preanesthetic medication (CASSU et al., 2011) instead of 30 minutes, as in our study. These findings may suggest that homeopathic medicines are more effective in dogs than in cats because, according to the homeopathic principles, the time to the onset of the effect is immediate (BENEZ, 2002).

While Arnica is indicated in traumatic injuries, here its effect on acute pain in the immediate 
postoperative period was not as satisfactory as expected. Two hypotheses may explain our results: 1) Arnica does not exert a satisfactory analgesic effect in the HSO postoperative period in cats, as about half of the animals required rescue analgesia, while perhaps the remainder of the cats did not need rescue medication as a function of the preventive analgesic effect of fentanyl, used in the induction of anesthesia (GORNIAK, 2011); and 2) the anti-inflammatory effect of Arnica is delayed, as KAWAKAMI et al. (2011) showed; thus, rescue analgesia was not needed six hours after the HSO. This second hypothesis may be corroborated by the study by BRONDANI et al. (2009), in which cats undergoing HSO, without previous administration of analgesics required rescue therapy for up to 32 hours after surgery. However, in that study, no fentanyl was administered.

As a function of the experimental conditions of the present study, it may be concluded that ketoprofen and morphine were more efficacious than Arnica and that there was no difference among the various potencies and routes of administration of Arnica relative to postoperative analgesia in cats undergoing HSO.

\section{ACKNOWLEDGEMENTS}

The Conselho Nacional de Desenvolvimento Tecnológico e Científico $(\mathrm{CNPq})$ for the doctoral grant and the funding of the study (503667/2007-2).

\section{BIOETHICS AND BIOSSECURITY COMMITTEE APPROVAL}

The study was approved by the institutional Committee of Ethics in Animal Experimentation, protocol 21/2008-CEEA. The animals' owners signed an informed consent form.

\section{REFERENCES}

BENEZ, S.M. Manual de homeopatia veterinária - Indicações clínicas e patológicas - Teoria e prática. São Paulo: Robe Editorial, 2002. 594p.

BRINKHAUS, B. et al. Homeopathic Arnica therapy in patients receiving knee surgery: results of three randomized double-blind trials. Journal of Complementary Therapies Medicine, v.14, n.4, p.237-246, 2006. Available from: <http://www.sciencedirect. com/science/article/pii/S0965229906000410>. Accessed: Nov. 12, 2008. doi: 10.1016/j.ctim.2006.04.004.

BRONDANI, J.T. et al. Analgesic efficacy of perioperative use of vetaprofen, tramadol or their combination in cats undergoing ovariohysterectomy. Journal Feline Medicine Surgery, v.11, p.420-429, 2009. Available from: <http://www.sciencedirect.com/ science/article/pii/S1098612X0800199X>. Accessed: Apr. 17, 2011. doi: 10.1016/j.jfms.2008.10.002.
BRONDANI, J.T. et al. Refinement and initial validation of a multidimensional composite scale for use in assessing acute postoperative pain in cats. American Journal of Veterinary Research, v.72, n.2, p.174-183, 2011. Available from: <http:// avmajournals.avma.org/doi/abs/10.2460/ajvr.72.2.174>. Accessed: Jan. 15, 2015. doi: 10.2460/ajvr.72.2.174.

BRONDANI, J.T. et al. Validity and responsiveness of a multidimensional composite scale to assess postoperative pain in cats. Arquivo Brasileiro de Medicina Veterinária e Zootecnia, v.64, n.6, p.1529-1538, 2012. Available from: <http://www.scielo. br/scielo.php?pid=S0102-09352012000600019\&script $=$ sci arttext>. Accessed: Jan. 15, 2015. doi: 10.1590/S010209352012000600019 .

BRONDANI, J.T. et al. Reliability and cut-off point related to the analgesic intervention of a multidimensional composite scale to assess postoperative pain in cats. Arquivo Brasileiro de Medicina Veterinária e Zootecnia, v.65, n.1, p.153-162, 2013. Available from: <http://www.scielo.br/scielo.php?pid=S010209352013000100024\&script=sci_arttext $>$. Accessed: Jan. 15, 2015. doi: 10.1590/S0102-09352013000100024.

CAMBRIDGE, A.J. et al. Subjective and objective measurements of postoperative pain in cats. Journal of American Veterinary Medical Association, v.217, n.5, p.685-690, 2000. Available from: $\quad<\mathrm{http} / /$ avmajournals.avma.org/doi/abs/10.2460/ javma.2000.217.685>. Accessed: Nov. 20, 2008. doi: 10.2460/ javma.2000.217.685.

CASSU, R.N. et al. Analgesic and anti-inflammatory effects of Arnica montana $12 \mathrm{CH}$ in comparison with ketoprofen in dogs. Ciência Rural, v.41, n.10, p.1784-1789, 2011. Available from: <http://www.scielo.br/scielo.php?pid=S010384782011001000018\&script $=$ sci_arttext\&tlng=en $>$. Accessed: Jan. 15, 2015. doi: 10.1590/S0103-84782011001000018.

CLAUSEN, J. et al. Veterinary clinical research database for homeopathy: placebo-controlled trials. Complementary Therapies in Medicine, v.21, p.115-120, 2013. Available from: <http:// www.sciencedirect.com/science/article/pii/S0965229912001653. Accessed: Jan. 17, 2015. doi: 10.1016/j.ctim.2012.11.009.

CORNU, C. et al. No effect of a homeopathic combination of Arnica montana and Bryonia alba on bleeding, inflammation, and ischaemia after aortic valve surgery. British Journal of Clinical Pharmacology, v.69, n.2, p.136-42, 2010. Available from: <http:// onlinelibrary.wiley.com/doi/10.1111/j.1365-2125.2009.03574.x/ full>. Accessed: Jan. 15, 2011. doi: 10.1111/j.13652125.2009.03574.x.

DOBBINS, S. et al. Comparison of the effects of buprenorphine, oxymorphone hydrochloride, and ketoprofen for postoperative analgesia after onychecyomy or onychectomy and sterilization in cats. Journal of the American Animal Hospital Association, v.38, p.507-514, 2002. Available from: <http://jaaha.org/ doi/abs/10.5326/0380507>. Accessed: Nov. 20, 2008. doi: $10.5326 / 0380507$.

GORNIAK, S.L. Hipnoanalgésicos e neuroleptoanalgesia. In: SPINOSA, H.S. et al. Farmacologia aplicada à medicina veterinária. 5.ed. Rio de Janeiro: Guanabara Koogan, 2011. p.170-179.

GUEDES, A.G. et al. Evaluation of histamine release during constant rate infusion of morphine in dogs. Veterinary Anaesthesia 
Analgesia, v.33, n.1, p.28-35, 2006. Available from: <http:// onlinelibrary.wiley.com/doi/10.1111/j.1467-2995.2005.00218.x/ full> Accessed: Nov. 20, 2008. doi: 10.1111/j.14672995.2005.00218.x

JEFFREY, S.L; BELCHER, H.J. Use of Arnica to relieve pain after carpal-tunnel release surgery. Alternative Therapies in Health and Medicine, v.8, n.2, p.66-68, 2002. Available from: <http:// search.proquest.com/docview/204823180?pq-origsite=gscholar $>$. Accessed: Nov. 20, 2008. doi: 11892685.

KAWAKAMI, A.P. et al. Inflammatory process modulation by homeopathic Arnica montana 6CH: the role of individual variation. Evidenced Based Complementary and Alternative Medicine, v.2011, 12p. Available from: <http://www.hindawi. com/journals/ecam/2011/917541/>. Accessed: Jan. 10, 2011. doi: $10.1155 / 2011 / 917541$.

LUNA, S.P.L. et al. Evaluation of adverse effects of oral long-term administration of carprofen, etodolac, flunixin meglumine, ketoprofen and meloxicam in dogs. American Journal of Veterinary Research, v.68, p.258-264, 2006. Available from: <http://avmajournals.avma. org/doi/abs/10.2460/ajvr.68.3.258?journalCode=ajvr $>$. Accessed: Nov. 20, 2008. doi: 10.2460/ajvr.68.3.258.

MACEDO, S.B. et al. Antiinflamatory activity of Arnica montana 6CH: preclinical study in animals. Homeopathy, v.93, p.84-87, 2004. Available from: <http://www.sciencedirect.com/science/ article/pii/S1475491604000098>. Accessed: Nov. 20, 2008. doi: 10.1016/j.homp.2004.02.006.

MARIANI, E. et al. Anthroposophical injectable Arnica montana extract in acute low back pain: a prospective study. European Journal of Internal Medicine, v.1, n.4, p.239-240, 2009. Available from: $<\mathrm{http}: / /$ www.sciencedirect.com/science/article/pii/S1876382009001589>. Accessed: Mar. 18, 2011. doi: 10.1016/j.eujim.2009.08.033

MATHIE, R.T. et al. Homeopathic prescribing for chronic conditions in feline and canine veterinary practice. Homeopathy, v.99, p.243-248, 2010. Available from: <http://www.sciencedirect. com/science/article/pii/S1475491610000597 . Accessed: Mar. 18, 2011. doi: 10.1016/j.homp.2010.05.010

MATHIE, R. T. et al. Randomised controlled trials of veterinary homeopathy: characterizing the peer-reviewed research literature for systematic review. Homeopathy, v.101, p.196 e 203, 2012. Available from: $<$ http://www.sciencedirect.com/science/article/pii/ S1475491612000513>. Accessed: Jan. 15, 2015. doi: 10.1016/j. homp..2012.05.009.

MENEGHELLO, J.L. Effects of ketofen, Arnica montana and electromagnetic field (radiofrequency) for postoperative analgesia in fellis catus submitted to ovariosalpingo hysterectomy. 2002. 77f. Dissertação (Mestrado em Cirurgia e Anestesiologia Veterinária) - Curso de Pós-graduação em Medicina Veterinária, Faculdade de Medicina Veterinária e Zootecnia, Universidade Estadual Paulista, Botucatu, SP.

ROBERTSON, A. et al. A. Homeopathic Arnica montana for post-tonsillectomy analgesia: a randomised placebo control trial. Homeopathy, v.96, p.17-21, 2007. Available from: <http://www. sciencedirect.com/science/article/pii/S1475491606001470>. Accessed: Nov. 20, 2008. doi: 10.1016/j.homp.2006.10.005.

ROBERTSON, S.A. et al. Antinociceptive and side-effects of hydromorphone after subcutaneous administration in cats. Journal of
Feline Medical Surgery, v.11, n.2, p.76-81, 2009. Available from: $<$ http:// www.sciencedirect.com/science/article/pii/S1098612X0800123X >. Accessed: Jan. 15, 2009. doi: 10.1016/j.jfms2008.05.003.

SEEMANN, A. et al. Variation of sesquiterpene lactone contents in different Arnica montana populations: influence of ecological parameters. Planta Medica, v.76, n.8, p.837-842, 2010. Available from: <https://www.thieme-connect.de/DOI/ DOI?10.1055/s-0029-1240797>. Accessed: Apr. 4, 2011. doi: $10.1055 / \mathrm{s}-0029-1240797$.

STANWAY, G.W. et al. A preliminary investigation comparing preoperative morphine and buprenorphine for postoperative analgesia and sedation in cats. Veteterinary Anaesthesia and Analgesia, v.29, p.29-35, 2002. Available from: <http://onlinelibrary.wiley. com/doi/10.1046/j.1467-2987.2001.00062.x/pdf>. Accessed: Nov. 20, 2008. doi: 10.1046/j.1467-2987.2001.00062.x.

STEVINSON, C. et al. Homeopathic Arnica for prevention of pain and bruising: randomized placebo-controlled trial in hand surgery. Journal of the Royal Society of Medicine, v.96, p.6065, 2003. Available from: <http://jrs.sagepub.com/content/96/2/60. full>. Accessed: Nov. 20, 2008. doi: 10.1258/jrsm.96.2.60.

TAYLOR, P.M. et al. Newer analgesics - nonsteroid antiinflammatory drugs, opioids and combinations. Veterinary Clinical of North America Small Animal Practice, v.29, n.3, p.719-735, 1999. Available from: <http://www.sciencedirect.com/ science/article/pii/S0195561699500570>. Accessed: Nov. 20, 2008. doi: 10.1016/ S0195-5616(99)50057-0.

TAYLOR, P.M.; ROBERTSON, S.A. Pain management in cats past, present and future. Part 1. The cat is unique. Journal of Feline Medical Surgery, v.6, p.313-320, 2004. Available from: <http:// www.sciencedirect.com/science/article/pii/S1098612X03001189>. Accessed: Nov. 20, 2008. doi: 101016/j.jfms2003.10.003.

TAKATA K.L. et al. Comparison of gastrointestinal adverse effects of ketoprofen between adult and young cats. Journal of Veterinary Medical Science, v.74, n.12, p.1545-1550, 2012. Available from: $<$ https://www.jstage.jst.go.jp/article/jvms/74/12/74_11-0563/ article>. Accessed: Jan. 15, 2015. doi: 10.1292/jvms.11-0563.

VALADÃO, C.A.A. et al. Evaluation of epidural morphine or ketamine analgesic effect in dogs by von Frey filaments. Arquivo Brasileiro de Medicina Veterinaria e Zootecnia, v.54, n.4, p.383-389, 2002. Available from: <http://www.scielo.br/scielo. php? script $=$ sci_arttext\&pid=S0102-09352002000400009>. Accessed: Nov. 12, 2008. doi: 10.1590/ S010209352002000400009 .

VICKERS, A.J.M.A. et al. Homeopathic Arnica 30x is ineffective for muscle soreness after long-distance running: a randomized, double-blind, placebo-controlled trial. Clinical Journal of Pain, v.14, n.3, p.227-231, 1998. Available from: <http://journals. lww.com/clinicalpain/Abstract/1998/09000/Homeopathic_ Arnica 30x Is Ineffective for Muscle.9.aspx>. Accessed: Nov. 12, 2008. doi: $\overline{10.1097 / 00002508-199809000-00009 .}$

VILELLA, G.T.A. et al. Avaliação da recuperação pós-operatória em cães com o uso complementar de Arnica montana $\mathrm{CH} 2$. Veterinária e Zootecnia, v.16, n.1, p.108-116, 2009. Available from: $<$ http://www.fmvz.unesp.br/rvz/index.php/rvz/article/view/395>. Accessed: Jan. 20, 2010. 